\title{
A Perfect Combination of the Real Life and Literary World: An Analysis of The Old Man and the Sea
}

\author{
CHEN Lian-feng \\ Northeast University at Qinhuangdao, Qinhuangdao, China
}

\begin{abstract}
Being distinguished from many greatest American writers, Hemingway is noted as an iron man and his powerful philosophy: "Man can be destroyed, but not defeated". Among all his works, The Old Man and the Sea is considered to be the masterpiece of Hemingway's works and the one that best demonstrates this powerful philosophy. And The Old Man and the Sea is a short novel about an old Cuban fisherman Santiago and his battle with a great marlin. In his masterpiece, Hemingway portrays Santiago with every dominant and strong characteristic, which is the prototype of an iron man. This is one of the basic characteristics of the novel which gives Ernest Hemingway great honor and makes him become one of the authors who define American literature. The Old Man and the Sea is the one that best represents American social life on the period Hemingway lived. In this short novel, a lot of facts are used. Most of the facts come from Hemingway's own experience. Reading up the masterpiece, it is evident that the story and the hero are the self-portray of the author himself. With the real life and the literary world perfectly combined, we read Hemingway's and we read through Hemingway and his inner world.
\end{abstract}

Keywords: Hemingway, The Old Man and the Sea, symbolism, real life, literary world

\section{Introduction}

The Old Man and the Sea is a short novel about Santiago, an old Cuban fisherman who has gone for 84 days without catch. Therefore, the boy, Mandolin, who used to sail with him, is forced to leave him and catch in another ship. The old man insists on fishing alone and at last, he hooks an eighteen-foot, giant marlin, the largest he has ever known. But the fish is very powerful and disobedient. It tows the old man and his boat out to sea for 48 hours, with the old man bearing the whole weight of the fish through the line on his back. The old man, with little food and sleep, has to endure much pain and fights against his treacherous hand cramp. To his great excitement, on his third day at sea, he succeeds in drawing the weakened marlin to the surface and harpoons it. On his way home, he lashes marlin alongside his boat because it is too big to be pulled into the boat. But, unfortunately, he comes across sharks in different numbers for four times. The old man fights to kill the sharks with as much might and many weapons as he can summon, but only to find a giant skeleton of his marlin left after his desperate defense. At last, Santiago, having lost what he fought for, reaches the shore and struggles to his shack. He falls into sound sleep, dreaming of Africa and the lions again. His struggle wins him much respect.

CHEN Lian-feng, associate professor, doctor, School of Languages, Northeast University at Qinhuangdao. 


\section{A New Understanding of Hemingway's Masterpiece}

\section{Santiago in the Story}

In Ernest Hemingway's The Old Man and the Sea, Hemingway portrays the old man, Santiago, with every dominant and strong characteristic. From the very first paragraph, Santiago is characterized as an old fisherman struggling against his pride and glory and also against defeat. He is looked down upon by other fishermen living in his village. But no matter what they say and how they sneer at Santiago, he is still a skilled fisherman and an undefeated man. And his pride, which is the source of his determination of setting out to the sea and enables his later greatness, makes him decide to fight for his success in the sea. His journey in the sea, however, is by no means an easy fight but accompanied by bad luck. He has gone 84 days without catching a fish-he will soon pass his own record of 87 days. Almost as a reminder of Santiago's struggle, the sail of his skiff resembles "the flag of permanent defeat" (Hemingway, 1998, p. 9). But "man is not made for defeat... a man can be destroyed but not defeated". The old man refuses defeat at every turn: He resolves to sail out beyond the other fishermen to where the biggest fish promise to be; he fights the powerful and disobedient marlin; he yields not to the shovel-nosed sharks but battle against them. He wins the respect and pride and remains undefeated.

\section{Santiago Beyond the Story}

Hemingway once said: "If a writer knows enough about what he is writing about, he may omit things that he knows. The dignity of movement of an iceberg is due to only one ninth of it being above water" (1999, p. 192). And he uses his iceberg theory well in his masterpiece, The Old Man and the Sea. Hemingway's book is not just another "fish tale". Its meaning is hidden among the characters and events for us, readers, to discover and interpret.

Some argue that Santiago symbolizes Christ in many ways. And that is by no means rootless but with certain reason.

The scars on the old man's hands are introduced in an opening description of Santiago. His hands "had the deep-creased scars from handling heavy fish on the cords. But none of these scars were fresh. They were as old as erosions in a fishless desert" (Hemingway, 1998, p. 10). Later, during his encounter with the marlin, the line cuts his right hand when the fish lurches. Santiago understands, "You're feeling it now, fish... And so, God knows, am I" (Hemingway, 1998, p. 56). Santiago's hands bleed and cramp recalls the image of Jesus Christ's hand bloodied by the nails used to crucify him. Santiago had cramps in his hands from holding the fishing line all night while he and the boat were being pulled by the strong fish. Hemingway wrote that the sounds Santiago made while having the cramps were the same as the reaction "someone would have while having a nail passed through their hand and into wood" (Hemingway, 1995, p. 80). This was the same experience Christ had while being crucified. When the old man returned to shore the boy, saw his hands, and began to cry just like Mary did at the foot of the cross when she saw the blood coming from Jesus. Also, after returning home, Santiago begins breaking down his ship and equipment. Santiago removes the mast and places it on his shoulders and walking to his shack "put the mast down and stood up. He picked the mast up and put it on his shoulder and started up the road. He had to sit down five times before he reached his shack" (Hemingway, 1998, p. 121); this is just like when Jesus Christ carried the cross through the town before he was crucified. The mast looked very like a cross and the cross was what Jesus was crucified on. Therefore, we can say that Santiago is not only Santiago himself; he could be the symbol of Jesus Christ. 


\section{A Perfect Combination of the Real Life and Literary World}

\section{A Comparison Between Santiago and Hemingway}

In order to fight for his pride and glory and against defeat, Santiago sets out his journey in the sea and battles with the natural world in the sea. And he finally succeeds in landing the marlin, defeats the sharks, and he achieves his goal and regains his pride, glory and respect at last.

Hemingway who was once frustrated by the unsuccessful marriages and mental weakness, on the other hand, encounters criticism from other writers. Having been knocked to the mat by the critics over Across the River, he got back to his feet and two years later issued the short work, The Old Man and the Sea, which clinched the Noble Prize for him. Despite what you might think of The Old Man and the Sea, it showed that Hemingway could still control his material if he wanted to.

\section{Facts or Symbolism?}

Many readers and critics say that Hemingway's work are not just common tale but has its deeper meaning. And Hemingway uses much symbolism to assist the readers with understanding of the massage he is trying to portray. But Hemingway himself proclaims,

There isn't any symbolism. The sea is the sea. The old man is an old man. The boy is a boy and the fish is a fish. Sharks are all sharks no better and no worse. All the symbolism that people say is shit. What goes beyond is what you see beyond when you know. (Baker, 2003, p. 780)

Is that sea are the sea and sharks are all sharks? Could Hemingway tell his reader another "fish tale"? Has he used symbolism in the story? In my opinion, the answer is definite. He did use symbolism. For example:

The books setting takes place near or on the ocean. To Santiago the ocean symbols life. In these days to live you have to eat and breathe. The ocean provides Santiago with fish for him to catch and eat and sell for a profit for other things. In life people face obstacles like Santiago did when he caught the fish he had to protect the fish from the sharks. The sharks symbolize people today, in that people are always looking for something. Since the Marlin is tied up the sharks have easy picking on the marlin and will keep eating and eating until the marlin is bare bones. People today keep taking and taking until there is nothing left. But in this story Santiago symbolizes the hard workingman in the world. He gets and goes out to catch fish so he can live another day. And when we overview the life story of Hemingway, it is easy to find a lot of similarities between the world Santiago live in and the harsh world in which the author has long struggled for his success.

\section{Conclusion}

To sum it up, the story of Cuban Fisherman Santiago is a reflection and a mirror of the author, Hemingway himself. The perfect combination between the real life of Hemingway and his literary works and the use of symbolism which remains controversial, shape an iron man in his masterpiece The Old Man and the Sea. And this echoes to Hemingway's powerful Philosophy "Man can be destroyed, but not defeated". Ernest Hemingway once said: "All good books have one thing in common - they are truer than if they had really happened" (Hotchner, 2005, p. 132). And The Old Man and the Sea is surely the masterpiece that cannot be truer than the real happened and makes Ernest Hemingway a Noble Prize Winner.

\section{References}

Baker, C. (2003). Ernest Hemingway selected letters 1917-1961. New York: Scribner. 
CHANG, Y. X. (2003). A brief history of American literature. Tianjin: Nankai University Press. Hemingway, E. (1995). The old man and the sea. New York: Scribner.

Hemingway, E. (1998). The old man and the sea. Beijing: World Publishing Corporation.

Hemingway, E. (1999). Death in the afternoon. New York: Scribner.

Hotchner, A. E. (2005). Papa Hemingway: A personal memoir. Boston, MA: Da Capo Press.

LI, G. Z. (2000). Selected readings of American literature. Xi'an: Xi' an Jiaotong University Press.

PENG, J. H. (2005). American literature. Wuhan: Huazhong University of Science and Technology Press. 